Published in "Geomorphology 206: 492-504, 2014"

which should be cited to refer to this work.

\title{
Monitoring of high alpine mass movements combining laser scanning with digital airborne photogrammetry
}

\author{
R. Kenner ${ }^{\text {a, } *}$, Y. Bühler ${ }^{\text {a }}$, R. Delaloye ${ }^{\mathrm{b}}$, C. Ginzler $^{\mathrm{c}}$, M. Phillips ${ }^{\mathrm{a}}$ \\ a WSL Institute for Snow and Avalanche Research SLF, Flüelastrasse 1, 7260 Davos Dorf, Switzerland \\ b University of Fribourg, Department of Geosciences, Geography Unit, ch. du Musée 4, 1700 Fribourg, Switzerland \\ c Swiss Federal Research Institute WSL, Zürcherstrasse 111, 8903 Birmensdorf, Switzerland
}

\begin{abstract}
Airborne- and terrestrial laser scanning are used in combination with digital airborne photogrammetry to monitor surface changes between 2009 and 2011 on rock glaciers and landslides at three mountain permafrost sites (Grabengufer, Schafberg and Flüela Pass) in the Swiss Alps. 3D surface changes detected through comparison of multitemporal laser scanning data, as well as horizontal creep rates determined using laser scanning data and digital airborne photogrammetry are analyzed. The methods applied allow comprehensive quantification of mass movements and volumetric changes, which are presented in 2.5D. GPS ground truths are used as reference data at the Grabengufer site. On the basis of this, a quality estimation is developed for the sites without GPS reference data. For changes with an extent of about $25 \mathrm{~m}^{2}$, a level of significance of $3 \mathrm{~cm}$ was obtained for both horizontal and vertical displacements under optimal measurement conditions. The complex dynamics of creeping and sliding permafrost features are investigated through analysis of their surface kinematics.
\end{abstract}

\section{Introduction}

In areas with alpine permafrost, active rock glaciers and deep-seated landslides are common forms of mass movement. Rock glaciers are the visible expression of cumulative deformation by long-term creep of ice/ debris mixtures under permafrost conditions (Berthling, 2011). They displace large volumes of rock debris-ice mixtures downslope at rates typically varying between several decimetres to metres per annum (Harris et al., 2009), with surges of up to several $\mathrm{m} \mathrm{a}^{-1}$ (Roer et al., 2008). The dynamics of these ice-rich features have recently been investigated (e.g., (Kääb et al., 2007) and are of particular interest as they can be highly variable due to external meteorological forcing (Delaloye et al., 2008) and the internal composition and rheological characteristics of rock glaciers. Factors affecting rock glacier creep include temperature, contents of debris, ice, and in particular, water (Kääb et al., 2007) as well as the underlying topography. The temporally and spatially variable, and sometimes quite unforeseeable nature of rock glacier dynamics is particularly relevant in the triggering of rockfalls and debris flows from the snout (Lugon and Stoffel, 2010). In addition to rock glaciers, active, often deep-seated landslides also occur in alpine permafrost areas. Their dynamics have so far not been investigated in detail, although like rock glaciers, they act as sediment conveyors on mountain slopes.

\footnotetext{
* Corresponding author. Tel.: +41 8141702 19; fax: +41 814170110. E-mail address: kenner@slf.ch (R. Kenner).
}

Active rock glaciers and landslides from which further highintensity sediment transfer processes such as rockfall and debris flows can occur must be monitored efficiently for successful hazard management. Three very common methods used to observe surface changes of mass wasting in unforested areas are digital airborne photogrammetry (DAP) and more recently, terrestrial- (TLS) and airborne lasers canning (ALS). Single point GPS measurements can be used to obtain precise reference data or to observe the kinematics of spatially limited areas (Lambiel and Delaloye, 2004). Photogrammetry is mainly used for the comprehensive detection of horizontal creep rates of rock glaciers over several decades (Kääb et al., 2003; Kellerer-Pirklbauer et al., 2007) but the detection of changes in surface elevation is also possible (Kääb, 1999; Kaufmann and Ladstädter, 2003). TLS/ALS make it possible to obtain information on vertical movements caused by subsidence, heave, slides and slumps etc. with a higher accuracy of up to a few $\mathrm{cm}$. This type of 3D deformation data were obtained by Bauer et al. (2003) and Bodin et al. (2008) for rock glaciers using terrestrial laser scanning. Further analysis also makes it possible to extract creep rates from multi-temporal point clouds. A higher accuracy can thus be reached than via photogrammetry (Bauer et al., 2003; Schwalbe et al., 2008), which is of practical interest to decision-makers in hazard zones with mass movements.

To develop an accurate and reliable monitoring technique for use in potentially hazardous areas, we measured mass movements in three permafrost areas in the Swiss Alps using DAP, TLS and ALS and in one case GPS for the time period of 2009 to 2011. The aims of this study 
are: 1) to compare and optimize the analysis of the data obtained using the remote sensing methods DAP, TLS and ALS; and 2) to find solutions to combine the different measurement systems in order to develop an integrated 2.5D rock glacier/landslide monitoring technique.

In addition, geodynamic processes observed during the measurement campaigns are presented.

\section{Site description and data sets}

\subsection{Grabengufer area, Randa}

The Grabengufer site is located at the western foot of the Grabenhorn peak above Randa in the Mattertal, Valais $\left(46^{\circ} 05^{\prime} \mathrm{N}, 7^{\circ} 48^{\prime} \mathrm{E}\right.$, WGS84, Fig. 1). It is characterised by very complex and dynamic terrain. The geometry of the mass movements and their kinematic behaviour were first detected by analysing satellite InSAR (Synthetic Aperture Radar Interferometry) data (Delaloye et al., 2007).

Fig. 2 shows a detailed overview of the individual terrain structures described below. There is an extensive deep-seated landslide feature at the foot of the rock slabs of the Grabenhorn west face (blue in Fig. 2) which is henceforth referred to as the Grabengufer landslide. On its orographic left border, the landslide collapses over a steep rock band, and during the observation period, voluminous erosion occurred from this failure scar (green in Fig. 2). Most of the material was deposited on the underlying Grabengufer rock glacier (red in Fig. 2). In 2009 this rock glacier showed extreme creep rates attaining up to about $100 \mathrm{~m}$ $\mathrm{a}^{-1}$ in its frontal part (Delaloye et al., 2010). Our terrestrial geodetic surveys show large seasonal fluctuations of the velocity and a decreasing trend of the velocity since the paroxysm of the surge in late 2009. Debris released by the rock glacier and some of the larger boulders issued from the upper failure scar fall into the large Grabengufer gully (yellow in Fig. 2) below the rock glacier front. Debris flows originating from here transport significant volumes of sediment through the Grabengufer and Dorfbach gullies and can be hazardous for the village of Randa (Bühler and Graf, 2012).

In 2010 and 2011 TLS and helicopter-borne ALS measurements were carried out. The TLS scan position and the spatial extent of the measurements can be seen in Fig. 2 including its inset, and details on the nature and timing of the measurements are given in Table 1.

\subsection{Rock glacier complex Foura da l' amd Ursina, Pontresina}

Foura da l'amd Ursina is a complex of three rock glacier features located in a cirque above Pontresina in the upper Engadin valley $\left(46^{\circ} 29^{\prime} \mathrm{N}, 9^{\circ} 55^{\prime} \mathrm{E}\right.$, WGS84, Fig. 1$)$. The site is surrounded by the peaks Las Sours to the north, Piz Muragl to the east and a rocky ridge called Muot da Barba Peider to the south (Fig. 3). The rock glacier in the orographic right sector of the cirque (red in Fig. 3) has a steep front located above the Val Giandains gully. Mass movements from this zone would be hazardous for two popular hiking trails crossing the upper part of Val Giandains. Pontresina is protected by a large avalanche and debris-flow retention dam at the base of the gully.

Terrestrial laser scanning was carried out from two different scan positions; on an avalanche protection wall west of the steep rock glacier front to observe the latter and on the ridge of Muot da Barba Peider to capture the remaining rock glacier complex (Fig. 3 and Table 1).

\subsection{Rock glacier Schwarzhorn, Flüela Pass}

The Schwarzhorn rock glacier has its root zone beneath the eastern sector of the north face of Flüela Schwarzhorn and its front reaches down to around $20 \mathrm{~m}$ from the Flüela Pass road $\left(46^{\circ} 44^{\prime} \mathrm{N}, 9^{\circ} 56^{\prime} \mathrm{E}\right.$, WGS84, Fig. 1). The rock glacier can be divided into three parts: an extensive terrace-like upper part, a narrow and steep central part and a tongue-shaped lower part.

Terrestrial laser scanning was carried out from a slope opposite to and to the north of the rock glacier. From there the central and lower parts of the rock glacier could be observed, but only fragments of the upper part. Fig. 4 shows an overview of the measurement site, and Table 1 gives measurement details.

\section{Data acquisition methods}

\subsection{Terrestrial laser scanning (TLS)}

TLS was carried out using a Riegl LPM321 Long Range Scanner. This instrument provides a single point accuracy of $25 \mathrm{~mm} @ 50 \mathrm{~m}+20$ ppm. The laser wavelength of $905 \mathrm{~nm}$ is suitable for rock as well as snow and ice. The scan process was managed over a laptop by the scanner software RiProfile. Data referencing was carried out using at least six geometrically and optimally distributed reflecting targets (Kenner et al., 2011). Coordinates of these targets were defined using a Leica total station. To reduce the influences of poor long term stability of the measurement setup, the instrument was reoriented regularly using the targets. A zone of stable terrain was always included within the scan area for accuracy analysis.

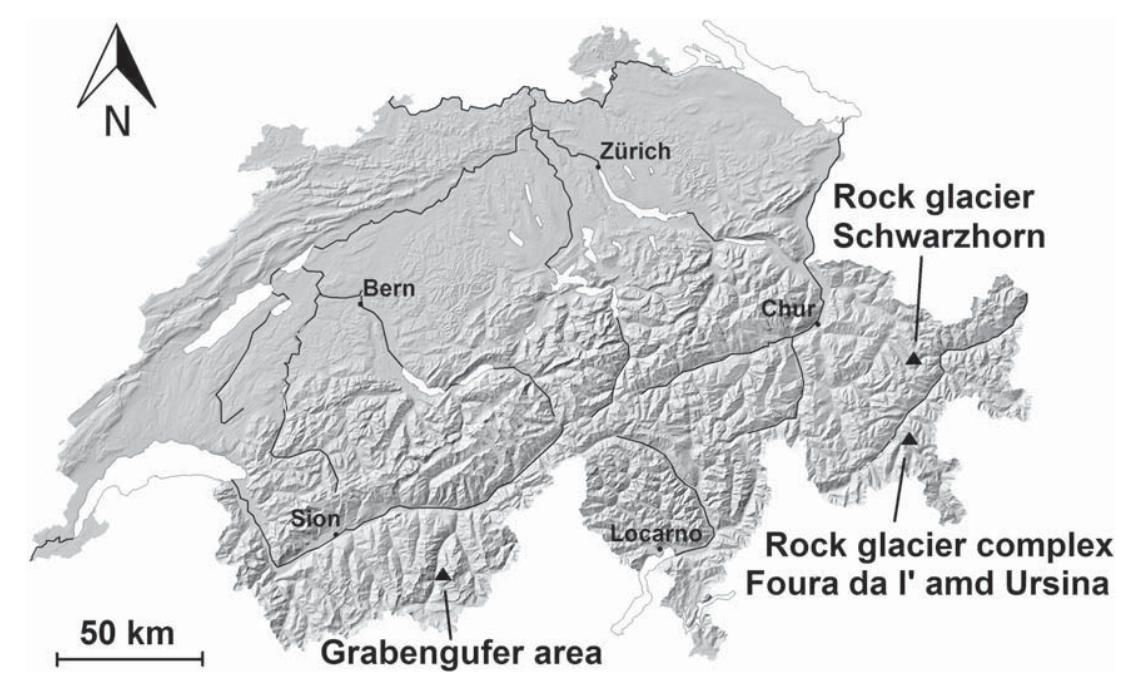

Fig. 1. Map showing the location of the study sites within Switzerland (Relief @ Swisstopo (JA100118)). 


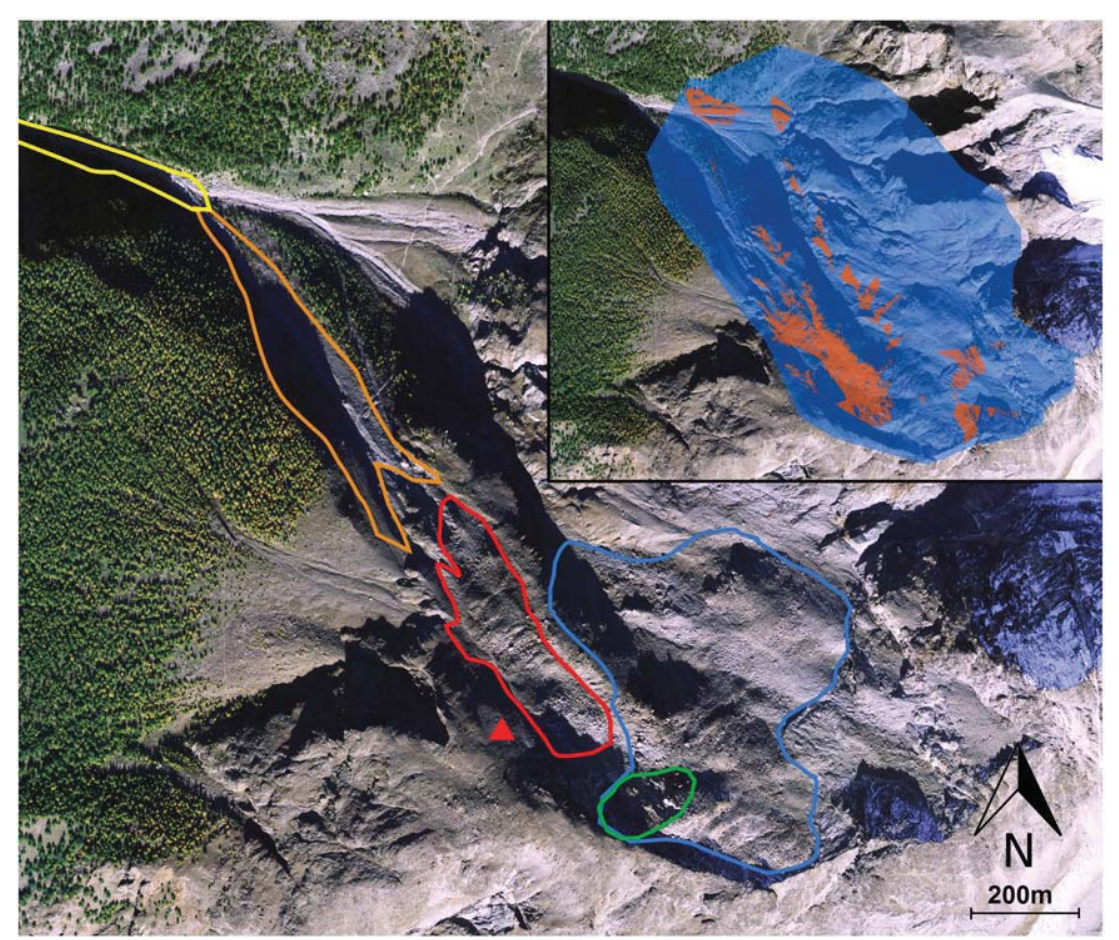

Fig. 2. Orthophoto of the Grabengufer site (orthophoto @ swisstopo DV03349.2). The terrain sectors mentioned in the text are shown in colour: yellow - Dorfbach gully; orange - Grabengufer gully; red - Grabengufer rock glacier; blue - landslide; green - failure scar; red triangle - TLS instrument position. Inset: Blue area - the upper part of the ALS perimeter. Orange area - sectors covered by TLS measurements.

\subsection{Airborne laser scanning (ALS)}

The helicopter-borne data ALS on the Grabengufer site was carried out using the handheld LiDAR/CCD/GPS/INS Sensor system developed by the Helimap System ${ }^{\circledR}$ company. This portable instrument provides a flexible field of application and can be mounted on various platforms. The manual handling allows an easy tilting of the sensor unit to achieve an optimal angle of impact. The centrepiece of the instrument is a Riegl 2D airborne scanner with a single point accuracy of $3 \mathrm{~cm} @ 40 \mathrm{~m}$ and $900 \mathrm{~nm}$ wavelength. The data were real time referenced by the integrated GPS and inertial navigation system (INS) (Skaloud et al., 2005; Bühler et al., 2012).

\subsection{Digital airborne photogrammetry (DAP)}

The digital airborne images used in this study were captured using the Leica airborne digital sensor ADS40/80. The sensor captures panchromatic, blue, green, red and the near-infrared images simultaneously, with different viewing angles. Georeferencing is initially done with a real time GNSS-INS combination and is followed by aerial triangulation using ground control points. Data from this sensor has been successfully applied in other studies in high alpine terrain (Bühler et al., 2009, 2012; Hobi and Ginzler, 2012).

The swissimage orthophoto (called OP I in the following) generated by Swisstopo has a ground resolution of $25 \mathrm{~cm}$, although the input

Table 1

Overview of the timing and resolution of the measurements carried out at each site. Descriptions of the methods and datasets are in Section 3.

\begin{tabular}{|c|c|c|c|c|c|}
\hline & TLS data & ALS data & $\begin{array}{l}\text { Swissimage } \\
\text { orthophoto (OP I) }\end{array}$ & $\begin{array}{l}\text { High resolution } \\
\text { orthophoto (OP II) }\end{array}$ & $\begin{array}{l}\text { GPS single point } \\
\text { measurements }\end{array}$ \\
\hline \multirow[t]{3}{*}{ Grabengufer } & 07.10 .2010 & 31.08 .2010 & 10.10.2006 & 06.10 .10 & 07.10 .2010 \\
\hline & 29.09.2011 & 07.07.2011 & & & 29.09.2011 \\
\hline & Resolution $<20 \mathrm{~cm}$ & Resolution $<50 \mathrm{~cm}$ & Resolution $25 \mathrm{~cm}(50 \mathrm{~cm})^{\mathrm{a}}$ & Resolution $25 \mathrm{~cm}$ & \\
\hline \multirow{6}{*}{$\begin{array}{l}\text { Foura da l'amd Ursina Rock } \\
\text { glacier front }\end{array}$} & $\overline{16.07 .2009}$ & $\overline{-}$ & $\overline{6.9 .2006}$ & $\overline{-}$ & - \\
\hline & 12.08 .2009 & & & & \\
\hline & 11.09.2009 & & & & \\
\hline & 21.07.2010 & & & & \\
\hline & 12.07.2011 & & Resolution $25 \mathrm{~cm}(50 \mathrm{~cm})^{\mathrm{a}}$ & & \\
\hline & Resolution $4 \mathrm{~cm}$ & & & & \\
\hline \multirow{4}{*}{$\begin{array}{l}\text { Foura da l'amd Ursina } \\
\text { remaining rock glacier } \\
\text { complex }\end{array}$} & $\overline{11.09 .2009}$ & - & 6.9.2006 & - & - \\
\hline & 04.08 .2010 & & & & \\
\hline & 18.08 .2011 & & & & \\
\hline & Resolution $20 \mathrm{~cm}$ & & Resolution $25 \mathrm{~cm}(50 \mathrm{~cm})^{\mathrm{a}}$ & & \\
\hline \multirow[t]{4}{*}{ Schwarzhorn rock glacier } & $\overline{25.09 .2009}$ & - & $\overline{15.10 .2005}$ & - & - \\
\hline & 15.09 .2010 & & & & \\
\hline & 22.08 .2011 & & & & \\
\hline & Resolution $20 \mathrm{~cm}$ & & Resolution $25 \mathrm{~cm}(50 \mathrm{~cm})^{\mathrm{a}}$ & & \\
\hline
\end{tabular}

${ }^{\text {a }}$ Resolution of the underlying aerial images. See Section 3.3 for detailed information. 


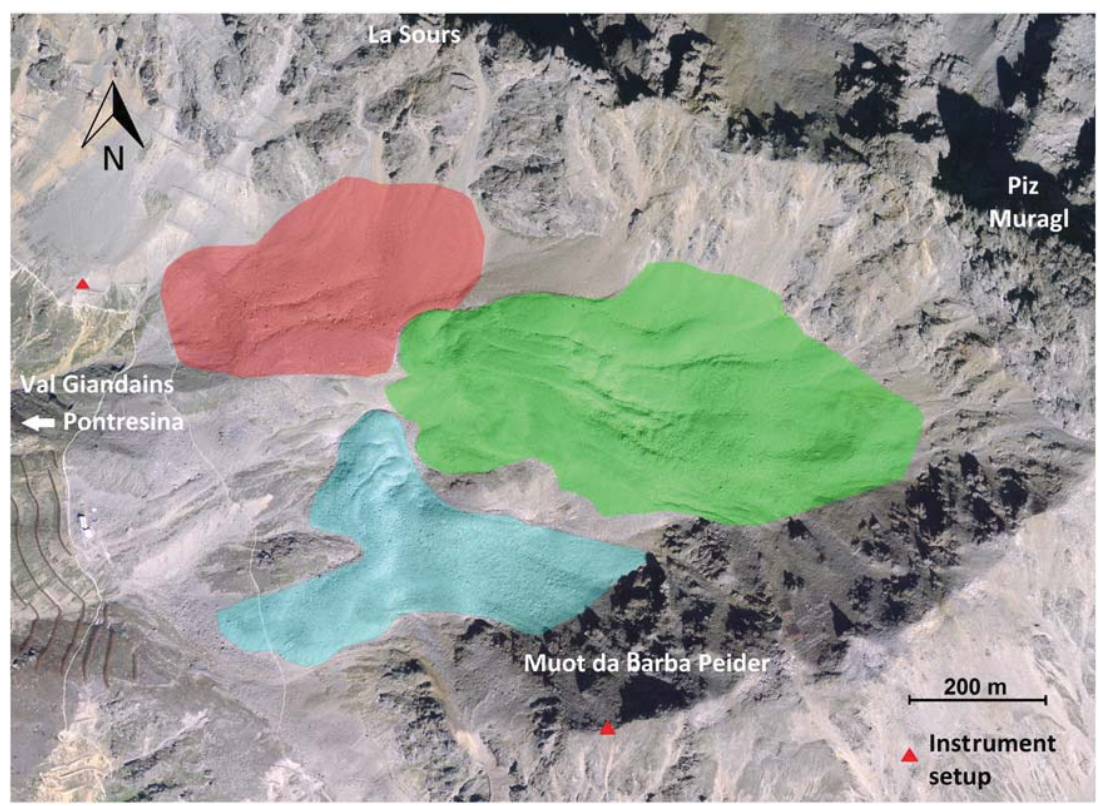

Fig. 3. Orthophoto of the rock glaciers Foura da l'amd Ursina (orthophoto @ Swisstopo DV03349.2). Different rock glacier systems are in blue, green and red, and red triangles show instrument positions.

ADS40 images have a resolution of $\sim 50 \mathrm{~cm}$. For reasons of countrywide homogeneity the final swissimage product has a resolution of $25 \mathrm{~cm}$. The reported horizontal accuracy is $3-5 \mathrm{~m}$ in steep, rough terrain. Above $2000 \mathrm{~m}$ a.s.l., a coarse digital elevation model derived from

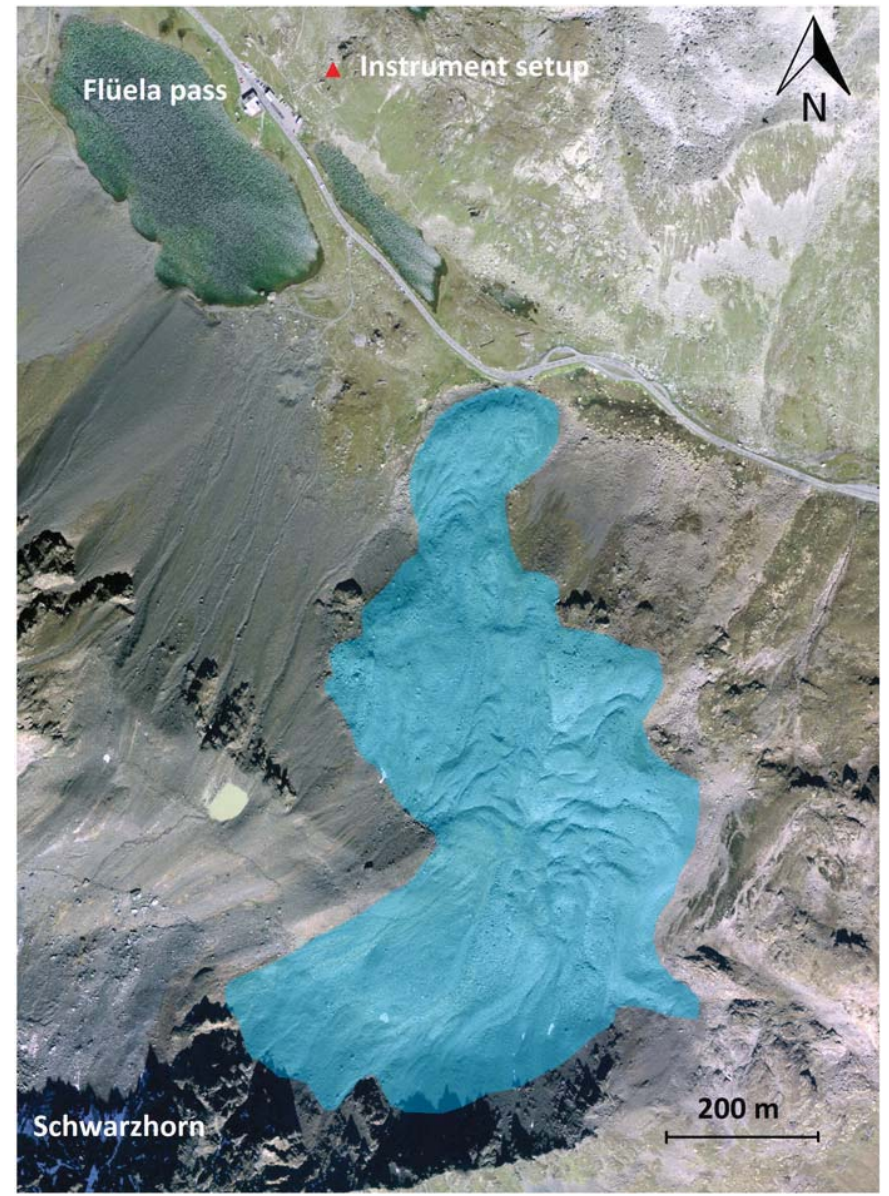

Fig. 4. Orthophoto of rock glacier Schwarzhorn (orthophoto @ Swisstopo DV03349.2). The rock glacier is in blue. topographic maps with $25 \mathrm{~m}$ resolution is used for orthorectification. The horizontal error is therefore expected to be higher in alpine terrain.

Additional ADS80 data were captured at the Grabengufer site in 2010. Due to the flight plan parallel to the slope, the ground sampling distance could be improved to $25 \mathrm{~cm}$. The ALS data was interpolated to a raster with $1 \mathrm{~m}$ resolution and used for orthorectification (Bühler et al., 2009; Hobi and Ginzler, 2012). The resulting high resolution orthophoto is called OP II hereafter.

\subsection{GPS measurements}

A total of 55 measurement points have been surveyed twice a year since 2009 using differential real time kinematic (RTK) GPS on both the Grabengufer rock glacier and the landslide. The GPS reference station was set up on a stable point close to the rock glacier (Lambiel and Delaloye, 2004). The accuracy of one single measurement in horizontal components is usually better than $3 \mathrm{~cm}$, mostly close to $1 \mathrm{~cm}$. The accuracy in elevation is slightly higher. As two measurements are necessary for determining displacement rates, the inaccuracy range of the RTK/GPS technique is about $5 \mathrm{~cm}$.

\section{Data analysis methods}

Several methods of measuring surface movements and their combinations are used in this paper. A graphic overview of the methods is given in Fig. 5 for the representative Grabengufer site.

\subsection{Combining multi-temporal point clouds from ALS or TLS}

\subsubsection{Vertical movements}

In the RiProfile software the TLS point clouds were transformed into a common coordinate system by applying a least squares matching of the measured targets in the different scan sessions. Subsequently the scans were geo-referenced using the coordinates of the targets. Relative iterative-closest-point (ICP) referencing was additionally applied in a few cases due to the presence of differential orientation errors within single scans (Kenner et al., 2011). In the next step, elevation rasters were generated from the ALS/TLS point clouds. The raster resolution values were defined by averaging the $z$ components of the points within one cell. The raster resolution was chosen to be close to the point cloud 


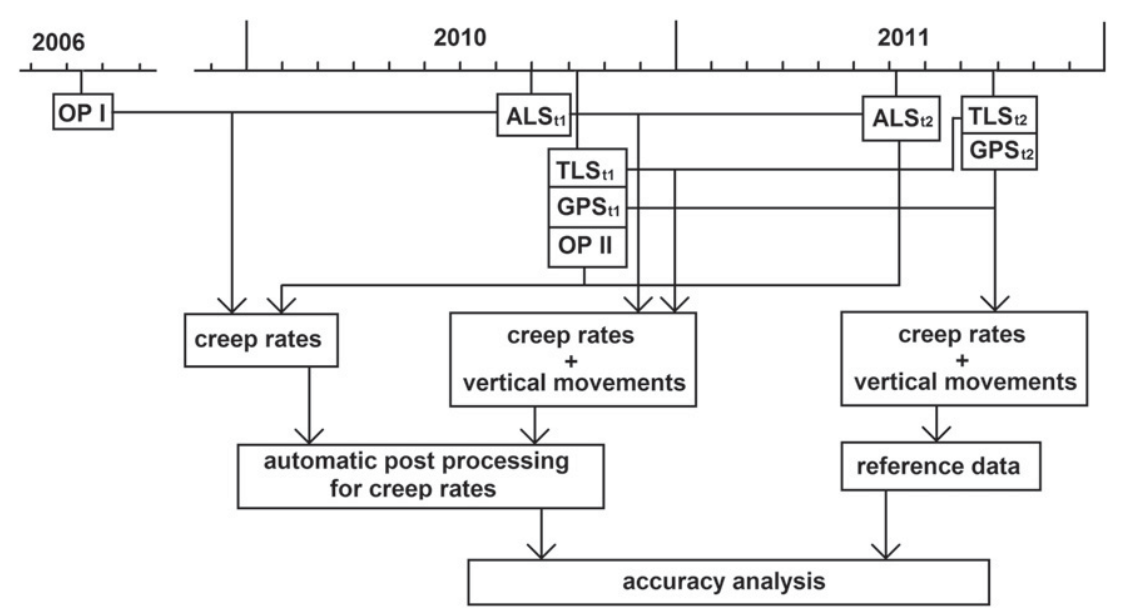

Fig. 5. Schematic description of the processes involved in the data acquisition and analysis at Grabengufer. OP: Orthophoto; TLS: terrestrial laser scanning; ALS: airborne laser scanning; GPS: GPS measurement; subscripts $\mathrm{t} 1$ and $\mathrm{t} 2$ : time points 1 and 2, respectively.

resolution. To compare the ALS raster data with the TLS data, the former were upsampled to the TLS raster resolution. To fill cells without data, we used a nearest-neighbour interpolation. The elevation values of multitemporal raster surfaces were subtracted from each other. In the resulting difference-raster, deformations or rapid mass movements could easily be identified. Deposit or erosion volumes were defined by adding up the difference-raster values over a specified spatial extent.

\subsubsection{Horizontal movements}

To calculate horizontal creep rates between the measurement campaigns, a high-pass filter was applied to the raster surfaces. Using a filter panel of $5 \times 5$ to $10 \times 10 \mathrm{~m}$, all large scale topography information was filtered out, leaving only the high frequency surface structure of the rock glacier. The resulting surfaces were grey-value scaled depending on their new $z$-value and saved as ordinary geo-referenced image files with the same extent and resolution for each image. As the surface structure of a rock glacier and hence the grey value pattern of the images mostly do not change in spite of slow creep, a correlation could be calculated between the multi temporal images. This was done by defining the shift of pattern between the images within patches of a given size using the particle imaging velocimetry method introduced by Roesgen and Totaro (1995). Translation vector components $\mathbf{u}$ in $x$-direction and $\mathbf{v}$ in $y$-direction were saved for each patch and converted from image to map units. Taking into account the amount of time between the measurements, we calculated creep velocity and direction for each patch.

The more common way to produce correlatable images out of raster data is to illuminate them using a hill-shade effect. We opted for the high pass filter, as it provides consistently good contrast in every exposition and inclination whereas hill-shade illumination can cause correlation errors (Bollmann et al., 2012). To compare creep rates obtained by different data combinations we joined each vector from the first dataset with the closest one from the second dataset, under the condition that the distance between them was smaller than the actual resolution.

\subsection{Combining laser scanning point clouds with airborne photogrammetry}

Raster surfaces were obtained similarly to the method described in Section 4.1.1. To compare them with orthophotos, we used a hill-shade effect, simulating the same lighting conditions as in the orthophoto. This led to similar light/dark contrast patterns between the orthophoto and the hill-shade raster. Both were again saved as referenced images, and creep movements were calculated as described in Section 4.1.2.

\subsection{Accuracy analysis}

\subsubsection{Accuracy of vertical movements}

The aim of our accuracy analysis was not to define the accuracy of DEMs but to define a level of significance (LOS) for change detection between raster datasets. As described in Kenner et al. (2011), the LOS of surface movements is highly dependent on the spatial extent of the movement. The larger the extent of a movement, the higher the LOS of the movement signal in the difference-raster (spatial out-filtering of errors). Hence, one single accuracy specification for the complete monitoring task is insufficient. Instead, the accuracy should be given in dependency of the extent of the movement.

We therefore used a technique based on matching repetition of unchanged terrain between two measurement campaigns. Using the stable parts of the difference-raster we calculated the arithmetic mean error $(A R M)$ for the surroundings of each cell. The calculation extent varied depending on the spatial extent of the surface movements of interest. Each single $A R M$ value removes all single cell random errors within its calculation extent. These errors play no role for the detection of an extensive change (spatial outfiltering). However ARM values conserve the important systematic large scale errors in their area. We calculated the absolute mean $(A B M)$ of all $A R M$ values to obtain a value that represents all extent-dependent large scale errors over the whole dataset. Adding the standard deviation (STDEV) of all ARM values to extent-dependent $A B M$, we obtained the value LOS. LOS is a mathematical specification of the LOS concept, representing the smallest detectable vertical movement with a horizontal spatial extent that corresponds to the calculation extent of $A R M$ values. Fig. 6 shows a simplified 1D concept of this procedure.

\subsubsection{Accuracy of creep rates}

To define a level of accuracy for the calculated creep rates we used two different approaches. The first and most significant way was to use control points measured by differential real time kinematic GPS. This was only possible for the Grabengufer site as it is the only one with GPS data. We calculated horizontal creep rates for each of the GPS points and reduced the values accordingly to the period of time between the ALS and TLS measurements. Due to the higher accuracy, the GPS creep rates were treated as true values. Hence we calculated residuals between every GPS creep vector and the closest image-based creep vector. We obtained the residuals as Cartesian $\mathrm{d} x$ and $\mathrm{d} y$ coordinates. We interpreted the mean value of these differences as a horizontal offset between the ALS/TLS/orthophoto input data of the image-matching algorithm. The image-based solution was corrected using this mean value. The corrected creep rates were transformed 


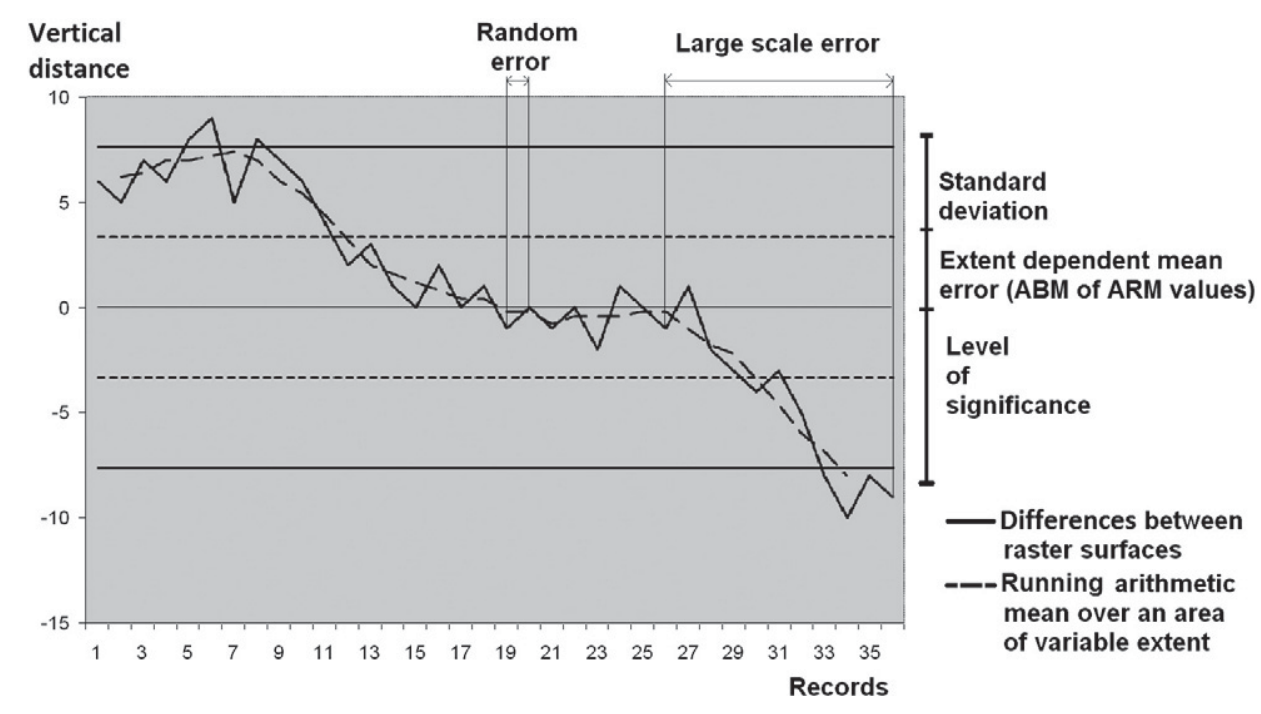

Fig. 6. Sketch showing the definition of the level of significance in difference-rasters.

into polar components (magnitude and direction) and residuals were calculated again. ABM and STDEV of the polar residuals quantify the obtained accuracy. This approach is analogous to the procedure described in Section 4.3.1. In this case the extent dependency of the mean error is realized by the size of the correlation window. To obtain accuracy for "annual creep rates", the magnitude has to be divided through the number of years between the measurements.

An estimation of accuracy without additional datasets was based on determining the plausibility of the resulting vector fields. A horizontal offset between the input data sets should be evident in a homogeneous and unidirectional shift of stable terrain and can be removed. LOS arises out of the smallest shift rates that can be displayed in a directed and plausible vector field. Calculations below this level result in chaotic vector fields with high frequency changes of magnitude and direction.

\subsubsection{Automatic post processing of vector fields}

Inevitably there are some large errors in most of the creep vector fields obtained. They are mainly single mismatches and larger areas with faulty correlations due to major changes of structure, shadow effects or homogeneity of surface pattern. The different superficial extension of these two kinds of errors makes it difficult to eliminate them fully automatically without a considerable loss of data. We obtained the best results with a relatively simple filter procedure. In the regular raster structure of the vector field we calculated STDEV of the angle for the $3 \times 3$ surroundings of each single vector. This calculation is difficult due to the discontinuous function of angle units. STDEV between neighbouring vectors of $360^{\circ}, 1^{\circ}$ and $2^{\circ}$ cannot be calculated in the common way. We therefore calculated the mean vector $v_{\mathrm{m}}$ of the $3 \times 3$ surrounding first:

$\nu_{\mathrm{m}}=\sum_{i=1}^{9} \frac{\nu_{i}}{\left|\nu_{i}\right|}$

where $v_{m}$ is the mean vector of a $3 \times 3$ vector array; $v_{i}$ is a set of single vectors within the $3 \times 3$ vector array; and $i$ is the running index.

In the next step we calculated the azimuth of $\nu_{m}$ and obtained the mean value for the standard deviation. The single differences for the standard deviation between azimuth $\nu_{i}$ and azimuth $\nu_{m}(\Delta A)$ were defined by a case-by-case analysis for $\Delta A<180^{\circ}(=\Delta A)$ and $\Delta A>180^{\circ}$ $(=360-\triangle A)$. For the STDEV value obtained we defined a threshold of $20^{\circ}$ for the maximum acceptable STDEV value of a $3 \times 3$ filter panel. All other vectors were eliminated. This led to a complete capture of all faulty correlations, but also affected a buffer zone of correct correlations around the incorrect ones. For example the entire $3 \times 3$ surroundings of a single mismatch lie above the given threshold. To counter this effect we performed a $3 \times 3$ dilatation on the elimination zone to recover the well-matched areas.

In the course of an iterative process the same procedure would also be possible using the length of the creep vectors as a disqualifier instead of the angle. However one iteration with angle values was sufficient here.

\section{Results}

Surface movements were quantified on the rock glaciers investigated. The differences in the multi-temporal raster surfaces revealed detailed changes in surface geometry. These mainly consisted of slides and rockfalls, as well as creep-induced heave and subsidence. Creep rates were defined using the cross-correlation matching technique.

\subsection{Grabengufer}

\subsubsection{Accuracy of vertical movements}

Surface changes were captured with the levels of significance specified in Table 2 between individual ALS measurements as well as between TLS measurements made in 2010 and 2011. Although there were some shadow effect induced data gaps in the TLS data, good results were obtained for the Grabengufer rock glacier and for monitoring the rockfall activity out of the failure scar. ALS provided a detailed overview of changes in a spatially continuous manner over the entire Grabengufer area, but the method has a lower LOS and resolution than TLS.

Table 2

Levels of significance for movements of different extent on Grabengufer rock glacier.

\begin{tabular}{|c|c|c|c|}
\hline Extent & $\begin{array}{l}\text { Extent dependent } \\
\text { mean }\end{array}$ & $\begin{array}{l}\text { Standard } \\
\text { deviation }\end{array}$ & $\begin{array}{l}\text { Level of } \\
\text { significance }\end{array}$ \\
\hline \multicolumn{4}{|l|}{ ALS measurements } \\
\hline Cell size $(0.5 \times 0.5 \mathrm{~m})$ & $10.8 \mathrm{~cm}$ & $15 \mathrm{~cm}$ & $\pm 25.8 \mathrm{~cm}$ \\
\hline $3 \times 3$ cells $(1.5 \times 1.5 \mathrm{~m})$ & $6 \mathrm{~cm}$ & $7.6 \mathrm{~cm}$ & $\pm 13.6 \mathrm{~cm}$ \\
\hline $20 \times 20$ cells $(10 \times 10 \mathrm{~m})$ & $3.9 \mathrm{~cm}$ & $4.4 \mathrm{~cm}$ & $\pm 8.3 \mathrm{~cm}$ \\
\hline \multicolumn{4}{|l|}{ TLS measurements } \\
\hline Cell size $(0.25 \times 0.25 \mathrm{~m})$ & $4.3 \mathrm{~cm}$ & $5.9 \mathrm{~cm}$ & $\pm 10.2 \mathrm{~cm}$ \\
\hline $3 \times 3$ cells $(0.75 \times 0.75 \mathrm{~m})$ & $2.7 \mathrm{~cm}$ & $3.8 \mathrm{~cm}$ & $\pm 6.5 \mathrm{~cm}$ \\
\hline $30 \times 30$ cells $(7.5 \times 7.5 \mathrm{~m})$ & $1 \mathrm{~cm}$ & $1.4 \mathrm{~cm}$ & $\pm 2.4 \mathrm{~cm}$ \\
\hline
\end{tabular}




\subsubsection{Accuracy of creep rates}

2D image matching was carried out between the two TLS datasets for the rock glacier, between the two ALS datasets, between ALS and OP I, and between ALS and OP II. As GPS data were available, a detailed accuracy analysis for creep rates on Grabengufer could be carried out as described in Section 4.3.2.

Image matching between the ALS datasets resulted in very detailed information on creep. In comparison with the GPS reference creep rates we unexpectedly found a significant horizontal offset between the ALS datasets (Table 3). After removing the offset by subtracting it from the obtained creep vectors, results over the entire measurement area became more plausible. Accuracy values for magnitude and direction after this post-processing step are presented in Table 4. As expected, these results were the most accurate ones at this site. In addition they confirm the creep rates obtained using the ALS and orthophoto combination described below.

A quality check of TLS to TLS matching using GPS reference data was not possible due to the lack of overlaps in the measurement areas (TLS was only available for the rock glacier). However, taking into account the different measurement dates and the extremely dynamic nature of the rock glacier, we can say that the TLS results correspond well to the ALS results (Table 4).

Image matching between ALS and the OP I provided surprisingly good results at this site (Table 4). Plausible creep rates were defined for the whole terrain sector excluding some smaller parts with mountain shade effects and the rapidly moving rock glacier due to important surface structure changes. Again, a significant horizontal offset between the datasets was found and removed (Table 3 ).

The accuracy values of ALS to OPI and ALS to OPII creep rates in Table 4 do not differ greatly, although OP II is based on the high resolution DEM. Some explanations for this will be presented in Section 6 . However, creep rates of the rapidly moving rock glacier could be documented with the help of OP II because the time lag between the measurements was shorter and thus the surficial structure changes were smaller.

We successfully tested the method described in Section 4.3 .3 for an independent and automatic analysis of creep fields at the three test sites. The results for the example of ALS and orthophoto correlation are documented here for the representative site of Grabengufer. The horizontal offset of $47 \mathrm{~cm}$ between these datasets in the $x$-direction detected with reference to the GPS data was visible in similar magnitudes in the unchanged terrain sectors of the raw vector field. After removing this offset we started the automatic processing and removed all apparent mismatches, as displayed in Fig. 7. We compared the results with the original creep zones, taking into account the LOS value of $23 \mathrm{~cm}$ obtained by GPS. Before post-processing, $2.8 \%$ of the creep vectors were below this $L O S$ value. Afterwards only $0.2 \%$ were marginally below. The smallest remaining creep rates after post-processing therefore correspond to the predefined LOS value. Hence we postulate coherence between the two methods of accuracy analysis: the GPSbased one and the one based on the vector fields themselves.

\subsubsection{Geodynamic processes}

The topography of the Grabengufer rock glacier changed significantly in the course of a year. Between 7 October, 2010 and 29 September, 2011 we observed a rockfall volume of $6500 \mathrm{~m}^{3}$ out of the failure scar above the rock glacier (pink outline in Fig. 8). Deposits of the same

Table 3

Horizontal offsets of ALS and OP I.

\begin{tabular}{lll}
\hline & Mean (offset) & Standard deviation \\
\hline Delta $x$ (ALS-ALS) & $-13 \mathrm{~cm}$ & $10 \mathrm{~cm}$ \\
Delta $y$ (ALS-ALS) & $-10 \mathrm{~cm}$ & $7 \mathrm{~cm}$ \\
Delta $x$ (ALS-OP I) & $47 \mathrm{~cm}$ & $13 \mathrm{~cm}$ \\
Delta $y$ (ALS-OP I) & $1 \mathrm{~cm}$ & $25 \mathrm{~cm}$ \\
\hline
\end{tabular}

Table 4

Accuracy values for creep rates at the rock glacier Grabengufer.

\begin{tabular}{|c|c|c|c|}
\hline & & $\begin{array}{l}\text { Absolute } \\
\text { mean }\end{array}$ & $\begin{array}{l}\text { Standard } \\
\text { deviation }\end{array}$ \\
\hline \multirow{2}{*}{$\begin{array}{l}\text { Accuracy of creep rates } \\
\text { between two ALS datasets }\end{array}$} & Magnitude $[\mathrm{cm}]$ & 5.9 & 4.9 \\
\hline & Direction $\left[{ }^{\circ}\right]$ & 9 & 8 \\
\hline \multirow{2}{*}{$\begin{array}{l}\text { Comparison of TLS creep rates } \\
\text { and ALS creep rates }\end{array}$} & Magnitude $[\mathrm{cm}]$ & 19 & 15 \\
\hline & Direction $\left[{ }^{\circ}\right]$ & 17 & 18 \\
\hline Accuracy of creep rates between & Magnitude $[\mathrm{cm}]$ & 12.9 & 10.3 \\
\hline ALS and OP I & Direction $\left[{ }^{\circ}\right]$ & 12 & 9 \\
\hline Accuracy of creep rates between & Magnitude $[\mathrm{cm}]$ & 9.7 & 11.7 \\
\hline ALS and OP II & Direction $\left[{ }^{\circ}\right]$ & 14.6 & 18.5 \\
\hline
\end{tabular}

order of magnitude appeared directly at the foot of the scar on the rock glacier rooting zone (black outline in Fig. 8). The structure of the rock glacier was also strongly affected by rapid creep, with tilting and rolling of large boulders and the development of new shear cracks and slump scars. In combination with the rough surface texture, this resulted in high frequency changes of elevation (white outline in Fig. 8). In the landslide zone, apparent heave and subsidence in the vertical range of $20 \mathrm{~cm}$ occurred in the dataset as the combined effect of the downslope creep and the rough surface texture.

During the same period, the rock glacier volume was reduced by about $12,000 \mathrm{~m}^{3}$. The mass balance was calculated between the ALS datasets for the whole rock glacier including the erosion zone in the failure scar and the deposit out of it.

The vector field for the section from the failure scar to the rock glacier downslope shows a succession of three distinct areas:

- A rapidly moving part directly beneath the failure scar with creep rates of up to $2 \mathrm{~m} \mathrm{a}^{-1}$ (yellow outline in Fig. 9)

- A slower part below with creep rates of apparently $<1 \mathrm{~m} \mathrm{a}^{-1}$ (green outline in Fig. 9)

- A rapidly creeping area corresponding to the rock glacier central part with widespread creep rates of 7 to $10 \mathrm{~m} \mathrm{a}^{-1}$ (orange outline in Fig. 9). This area was moving up to $30 \mathrm{~m} \mathrm{a}^{-1}$ in October 2009.

The frontal part of the rock glacier moved even more rapidly with a horizontal velocity of up to $30-50 \mathrm{~m} \mathrm{a}^{-1}$ during the same observation period, as estimated from photographs. However, this could not be captured by TLS/ALS due to strong changes in surface structure.

The majority of the landslide zone showed creep rates ranging between 20 and $45 \mathrm{~cm}$ in 10 months (ALS to ALS), or 70 and $200 \mathrm{~cm}$ in four years (ALS to OP I). Creep of $40 \mathrm{~cm}$ in 10 months or $200 \mathrm{~cm}$ in 4 years respectively occurred above the failure scar. Superimposed on the landslide we could observe a small, rapid creeping feature to the east of the Grabengufer rock glacier (red ellipse in Fig. 9). Except those on the Grabengufer rock glacier, the highest creep rates ( $80 \mathrm{~cm}$ in 10 months) occur in this part. They differ from the otherwise spatially homogenous creep rates of the landslide.

\subsection{Foura da l'amd Ursina}

\subsubsection{Accuracy analysis}

On the basis of redundant multi-temporal TLS measurements we defined vertical surface changes of up to $2.5 \mathrm{~cm} \mathrm{a}^{-1}$ on the steep rock glacier front. For the remaining rock glacier complex we obtained the levels of significance shown in Table 5 . The equality of the mean value for $60 \times 60 \mathrm{~cm}$ and that of $6 \times 6 \mathrm{~m}$ is proof of a vertical global offset of $2.2 \mathrm{~cm}$ between the datasets.

Under ideal measurement conditions (i.e. short measurement ranges, good overview, and very stable instrument setup) and terrain properties (flat terrain with a regularly rough blocky surface), creep rates of up to $3 \mathrm{~cm}$ could be defined using the multi temporal TLS data. Large spatial data gaps due to shadow effects, however, made it 

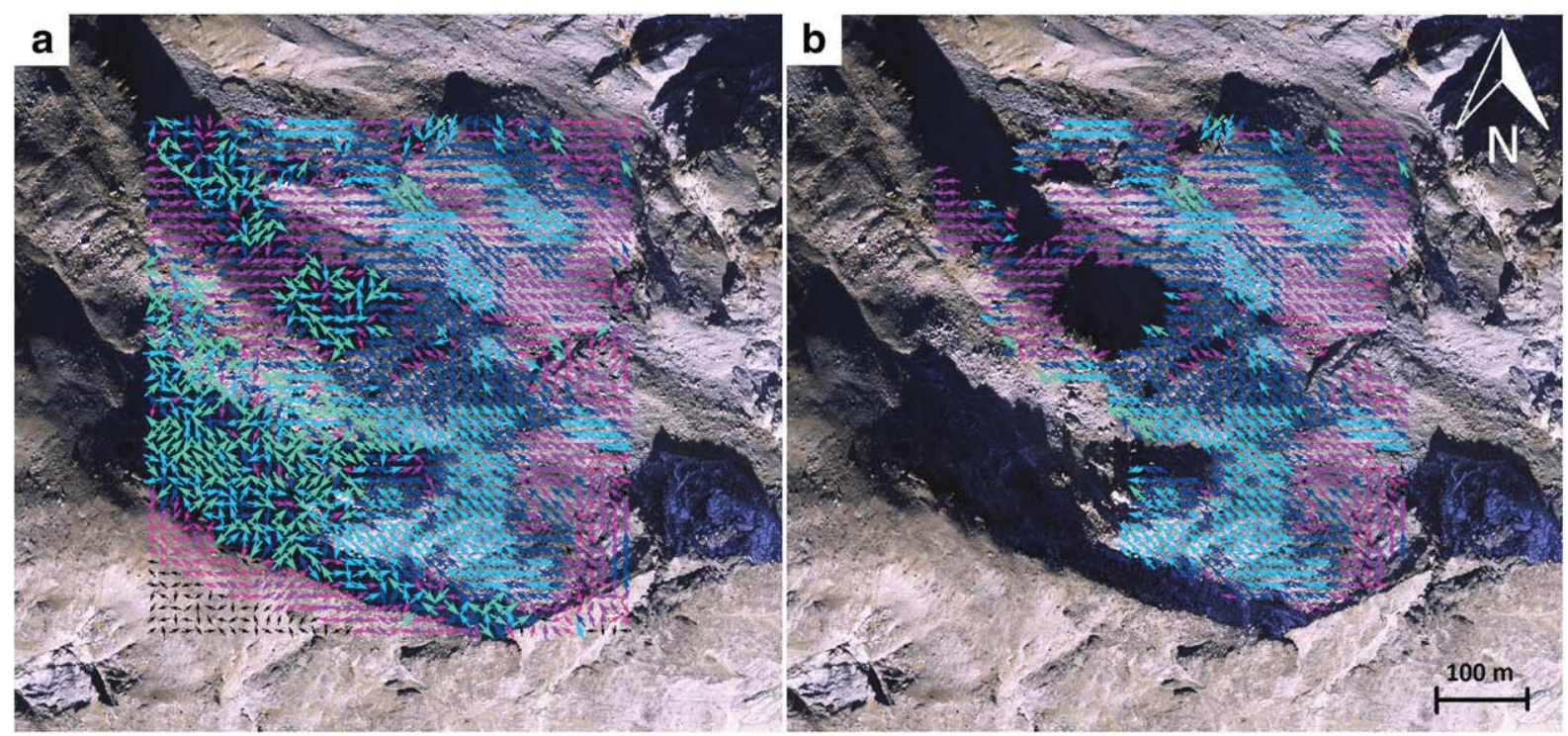

Creep rates $[\mathrm{cm}]$

$\uparrow<25$

个 $25-50$

个 $50-100$

^ $100-150$

$150-200$

$<200$

Fig. 7. Creep rates obtained between ALS and OP1 at Grabengufer before (a) and after (b) automatic post-processing. Most of the mismatches are eliminated but a few areas with incoherent vector fields remain due to poor illumination or orthophoto distortions at terrain steps.

impossible to define a detailed creeping field for the entire rock glacier complex (Fig. 10).

Although LOS for OP I and TLS matching was similar to the other sites, it was impossible to differentiate movements from systematic errors. The rock glacier dynamics at Foura da l'amd Ursina are much smaller and therefore not significant.

\subsubsection{Geodynamic processes}

A proof of the stability of the rock glacier could be established for the potentially hazardous front. Only small slides with a total volume of $9 \mathrm{~m}^{3}$ could be observed between 2009 and 2011 ( 8 in Fig. 10).

Creep of three different rock glaciers could be observed (Fig. 3). The fastest creep occurred on the upper rock glacier (green in Fig. 3) with a

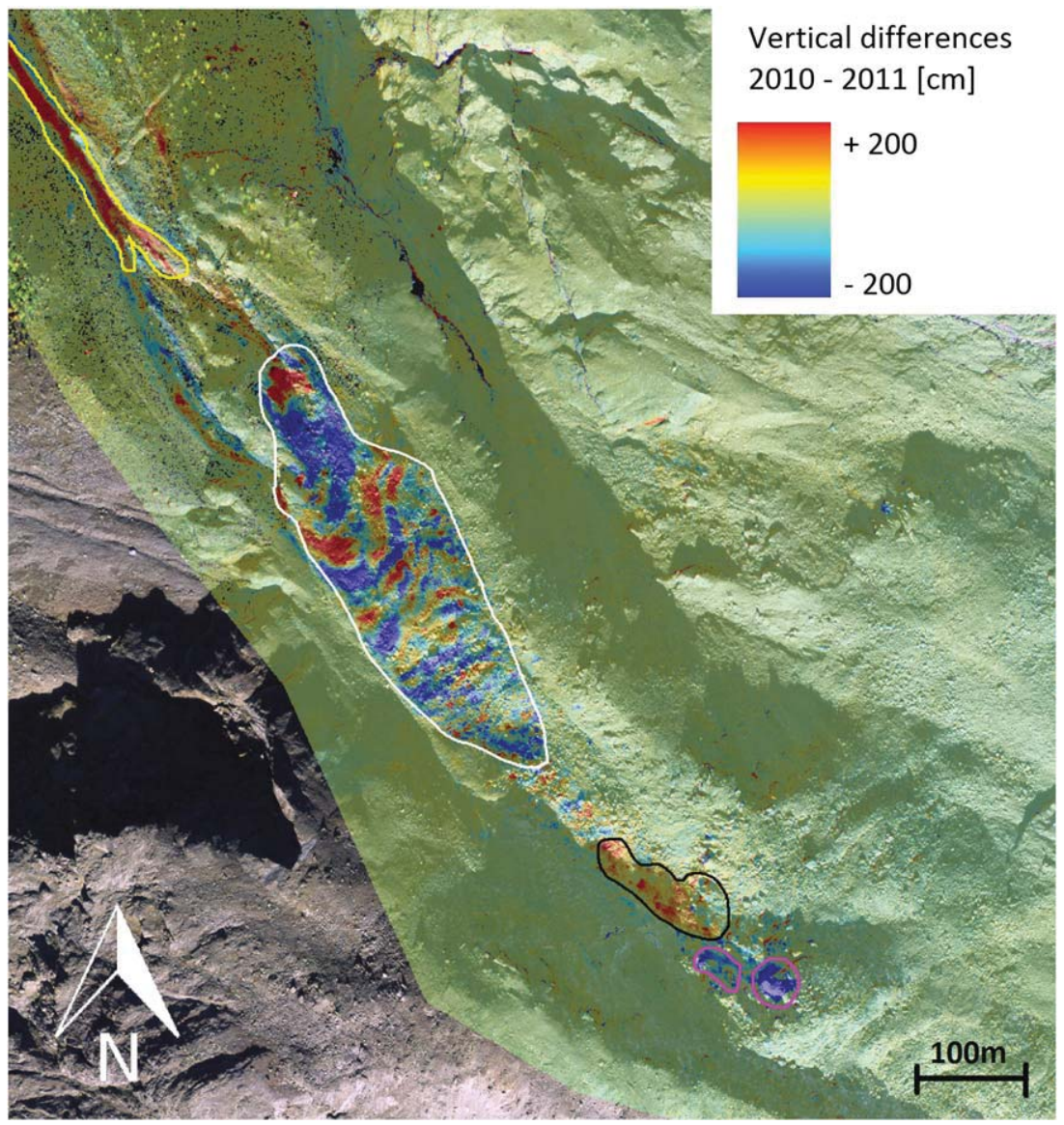

Fig. 8. Vertical movements at the Grabengufer site between the ALS datasets (31 August, 2010 to 7 July, 2011). Pink outline: failure scar of rockfall. Black outline: main rockfall deposit. White outline: high frequency change in elevation due to rapid creep. Yellow outline: filling of the main debris flow channel (active on 14 August, 2010 ) by debris fallen from the rock glacier. 


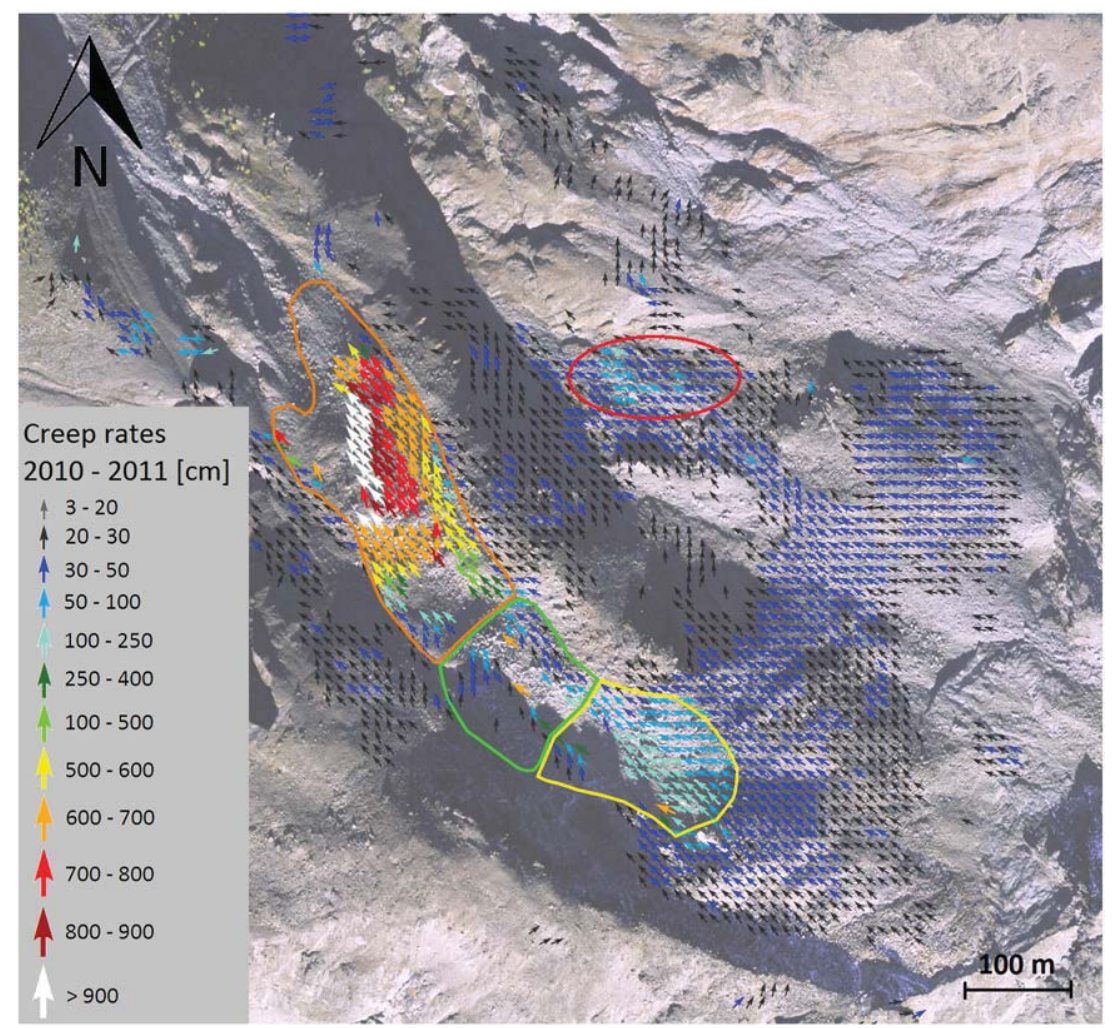

Fig. 9. Creep rates at the Grabengufer site calculated between the ALS datasets. Areas without creep rates are not equivalent to stable terrain but include terrain without proper matching solutions. The rapidly creeping feature, superimposed on the landslide is located within the red ellipse. The areas of different creep velocity on the rock glacier, described in Section 4.4 .2 , are outlined in orange, green and yellow.

maximum of $20 \mathrm{~cm} \mathrm{a}^{-1}$. In accordance with the creep rates, heave and subsidence occurred downslope or upslope of these rapidly moving parts (1 in Fig. 10). Kääb (1999) also mentioned these parts as being the most active. On the orographic leftmost rock glacier in the cirque we could observe creep rates of about $3 \mathrm{~cm}$ in 2 years (2 in Fig. 10). At its front, however, there are two tongues with faster creep rates of up to $15 \mathrm{~cm}$ in 2 years. This is associated with clear subsidence here (3 in Fig. 10). The orographic right rock glacier at the base of the scree slopes of La Sours showed creep rates of $15 \mathrm{~cm}$ in 2 years in its root zone (4 in Fig. 10) but only marginally significant movement at its snout, which forms the potentially hazardous front at the top of the Val Giandains gully (5 in Fig. 10). In addition to these creep phenomena, a rockfall of about $650 \mathrm{~m}^{3}$ occurred in the southern rock wall of the cirque in 2011 (6 in Fig. 10) and a voluminous slide occurred next to a damaged artificial wall (7 in Fig. 10).

\subsection{Schwarzhorn rock glacier (Flüela Pass)}

\subsubsection{Accuracy analysis}

Based on TLS measurements in 2009 and 2011, we could capture vertical surface changes with the levels of significance shown in

\section{Table 5}

Levels of significance for movements of different extent on the rock glacier Foura da l'amd Ursina.

\begin{tabular}{llll}
\hline Extent & $\begin{array}{l}\text { Extent dependent } \\
\text { mean }\end{array}$ & $\begin{array}{l}\text { Standard } \\
\text { deviation }\end{array}$ & $\begin{array}{l}\text { Level of } \\
\text { significance }\end{array}$ \\
\hline Cell size $(0.2 \times 0.2 \mathrm{~m})$ & $2.6 \mathrm{~cm}$ & $2.3 \mathrm{~cm}$ & $\pm 4.9 \mathrm{~cm}$ \\
$3 \times 3$ cells $(0.6 \times 0.6 \mathrm{~m})$ & $2.2 \mathrm{~cm}$ & $1.1 \mathrm{~cm}$ & $\pm 3.3 \mathrm{~cm}$ \\
$30 \times 30$ cells $(6 \times 6 \mathrm{~m})$ & $2.2 \mathrm{~cm}$ & $0.6 \mathrm{~cm}$ & $\pm 2.8 \mathrm{~cm}$ \\
\hline
\end{tabular}

Table 6. Creep rates were calculated between these datasets and automatic post-processing of the vector fields resulted in a surprisingly high LOS of $3 \mathrm{~cm}$ (Fig. 11).

Although there are some clear systematic errors, image matching between TLS data from 2010 and OP I from 2005 shows very similar results. We compared the annual creep rates obtained by both approaches and found a good agreement. A mean value of $-25 \mathrm{~cm}$ and a standard deviation of $14 \mathrm{~cm}$ were obtained for the magnitude. A mean of $10^{\circ}$ and a standard deviation of $25^{\circ}$ were obtained for direction. There are two possible explanations for the high mean value in the creep magnitude. One is that creep recently slowed down. However, the simultaneously much lower standard deviation would imply that all parts of the rock glacier slowed down at once, which is not very likely. Therefore the second explanation could be a systematic offset between the TLS and orthophoto, which is hard to prove due to the lack of stable areas in both measurements.

\subsubsection{Geodynamic processes}

The dynamics of Schwarzhorn rock glacier presented in Fig. 11 was mainly limited to creep processes. Creep rates show a constant movement of about $40 \mathrm{~cm}$ in 2 years in the upper and lower zones and about $100 \mathrm{~cm}$ in 2 years in the centre of the steep middle part. Uplift and subsidence could also be observed, reflecting the complex terrain form and the creep processes. Most of the vertical movements correspond to the presence of crescent shaped ridges and furrows at the surface of the creeping mass. A zone of uplift is also clearly visible at the steep creeping front. Based on the current creep rates, the rock glacier will overrun the Flüela pass road in less than 100 years. In addition to creep processes we observed two small rockfalls, one at the front $\left(2 \mathrm{~m}^{3}\right)$ and one in the rapidly moving steep zone $\left(8 \mathrm{~m}^{3}\right)$. 


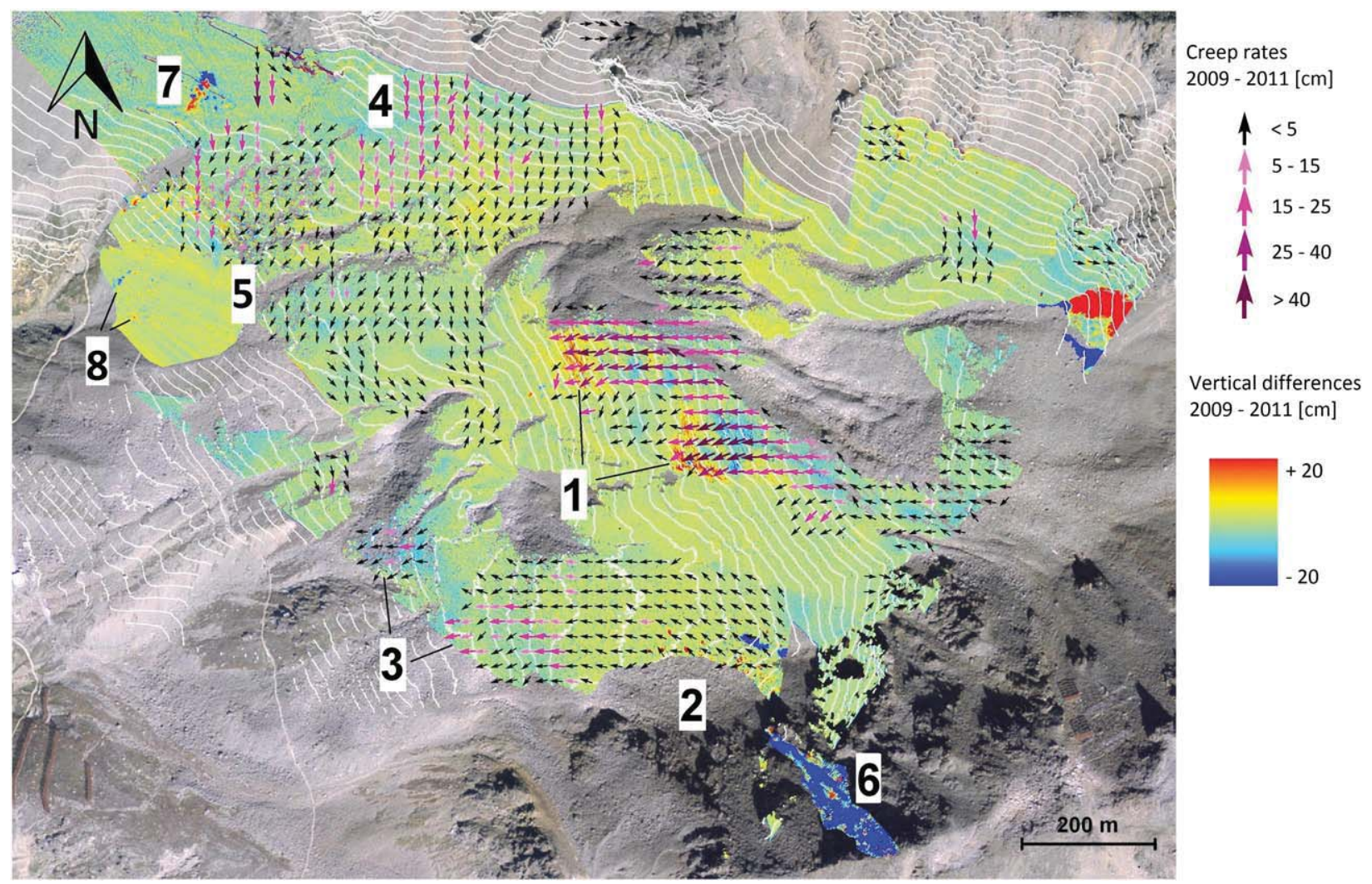

Fig. 10. Vertical movements and creep rates of the Foura da l'amd Ursina rock glaciers between 2009 and 2011. The labeled areas of movement are described in the text (orthophoto $\odot$ Swisstopo DV03349.2).

\section{Discussion}

\subsection{Applications of the method}

All three measurement methods (TLS, ALS, and airborne photogrammetry) applied in our study showed advantages and disadvantages which are highly dependent on the conditions at the measurement site and on the aim of the measurements. It is therefore recommended to carry out an evaluation of applicability for the different methods in every single case. Some criteria for this are given in Table 7.

Our study confirms that combinations of different remote sensing methods are possible and provide reliable results. The presented combination of laser scanning data and orthophotos for the quantification of creep processes produced useful results for the two measurement sites of Grabengufer and Flüela. The residuals between the processed creep rates and those measured by GPS at Grabengufer were surprisingly small. One explanation for this is the size of the cross-correlation window. At Grabengufer we used a window size of about $15 \mathrm{~m}$. This is near the resolution of the DEM used for processing OP I and clearly above the resolution of ALS. Both the differential distortions in the orthophoto and the random errors in the point cloud were filtered out to a great extent. It was therefore necessary to find a good compromise for the size of the correlation window concerning error minimization and the desired spatial resolution of the creep rates.

Table 6

Levels of significance for movements of different extent at the Schwarzhorn rock glacier.

\begin{tabular}{llll}
\hline Extent & $\begin{array}{l}\text { Extent dependent } \\
\text { mean }\end{array}$ & $\begin{array}{l}\text { Standard } \\
\text { deviation }\end{array}$ & $\begin{array}{l}\text { Level of } \\
\text { significance }\end{array}$ \\
\hline Cell size $(0.4 \times 0.4 \mathrm{~m})$ & $5.1 \mathrm{~cm}$ & $6.5 \mathrm{~cm}$ & $\pm 11.6 \mathrm{~cm}$ \\
$3 \times 3$ cells $(1.2 \times 1.2 \mathrm{~m})$ & $2.7 \mathrm{~cm}$ & $3.4 \mathrm{~cm}$ & $\pm 6.1 \mathrm{~cm}$ \\
$20 \times 20$ cells $(8 \times 8 \mathrm{~m})$ & $1.7 \mathrm{~cm}$ & $1.8 \mathrm{~cm}$ & $\pm 3.5 \mathrm{~cm}$ \\
\hline
\end{tabular}

However, the combination of laser scanning and orthophotos has clear limits regarding accuracy, terrain inclination and surface structure. The results will therefore always require careful interpretation. With

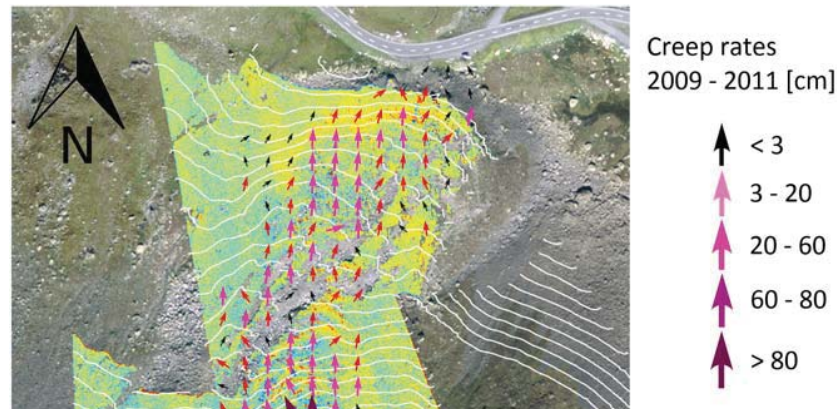

Vertical differences $2009-2011[\mathrm{~cm}]$

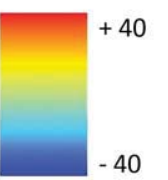

Fig. 11. Vertical movements and creep rates of the Schwarzhorn rock glacier between 2009 and 2011 (orthophoto @ Swisstopo DV03349.2). 
Table 7

Strengths and weaknesses of the different remote sensing techniques used.

\begin{tabular}{|c|c|c|c|}
\hline & TLS & ALS & DAP \\
\hline Accuracy & $>\mathrm{cm}$ & $>\mathrm{dm}$ & $>\mathrm{dm}$ \\
\hline Resolution & $>\mathrm{dm}$ & $<\mathrm{m}$ & $>\mathrm{dm}$ \\
\hline Shadow effects & $\begin{array}{l}\text { strong } \\
\text { influence }\end{array}$ & no influence & in very steep terrain \\
\hline 3 Dimensionality & directly & directly & indirect in lower quality \\
\hline Natural radiation & independent & independent & $\begin{array}{l}\text { dependent } \\
\text { (shadows/different lighting } \\
\text { condition }\end{array}$ \\
\hline $\begin{array}{l}\text { Costs (equipment/ } \\
\text { application) }\end{array}$ & high & very high & very high \\
\hline Range & local & regional & national \\
\hline Time series & short & short & often several decades \\
\hline Image information & $\begin{array}{l}\text { possibly } \\
\text { indirect }\end{array}$ & $\begin{array}{l}\text { possibly } \\
\text { indirect }\end{array}$ & direct and exact \\
\hline
\end{tabular}

regard to the accuracy values obtained at Grabengufer, the GPS points do not lie within zones with abrupt changes in altitude. Hence, the accuracy specifications given here refer mainly to slope angles below $25^{\circ}$. This explains why there is no increase in accuracy for the creep rates calculated between the ALS data and OP II (see Section 5.1.2.). It seems that the resolution of the DEM used for orthorectification does not play such an important role in the relatively homogenous surface of the rock glacier, especially if a large correlation window is used. Obviously, other distortions which are not elevation-dependent have a stronger influence. In contrast, apparent creep next to abrupt topographical changes is an example of errors which are difficult to avoid. In addition, a horizontal offset between the datasets has to be expected and must be taken into account. It is recommendable to involve large parts of stable terrain in the measurements to define those offsets without additional data. Creep rates registered in shadow zones of the orthophoto are in general erroneous. Zones with strong changes in surface structure (e.g. after a rockfall event) or zones with a very monotonous surface structure can also lead to failure of the image matching algorithm. Nevertheless, the combination of ALS and orthophoto technique for creep rate calculation can be useful in hazardous situations when results are required rapidly. A single ALS measurement in combination with the most recent orthophoto can be sufficient to define creep rates.

The extent dependent accuracy analysis and the automatic creep rate post-processing presented in this study have proved to be suitable tools for an objective proof of the quality of the data measured. A main advantage of these methods is the independence of reference data. Instead, the relative precision of the monitoring measurements is analyzed, which corresponds to the accuracy of the changes captured. The big differences between the LOS values for vertical changes of nearly one magnitude for different movement extents underline the need to consider the extent dependency. Other factors that lead to clearly different $L O S$ values between the sites are the range dependency of resolution and orientation errors (e.g. Schwarzhorn rock glacier > > Foura da l'amd Ursina) but also the measurement geometry. In spite of equal measurement ranges the LOS values on Grabengufer are not as good as on Foura da l'amd Ursina due to poor angles of impact.

\subsection{Dynamics of mass movements}

The extensive surge of the rock glacier on Grabengufer is still continuing and the fast moving part $\left(>5 \mathrm{~m} \mathrm{a}^{-1}\right)$ at the rock glacier front has a length of nearly $250 \mathrm{~m}$. An interruption of rockfall and debris flow activity is therefore not to be expected in the near future. Most of the $12,000 \mathrm{~m}^{2}$ material lost in the observation period was probably transferred into the underlying Grabengufer gully. Another factor contributing to the reduction in volume could be loss of ice. The surface structure of the large mass wasting area to the north and east of the rock glacier that displays surface creep of at least $20 \mathrm{~cm} \mathrm{a}^{-1}$ is most likely one single but complex deep-seated landslide feature with different compartments. In its eastern part, the landslide is partly covered by debris fallen from the Grabenhorn and apparently moves as two superimposed rock glacier features. Due to the extensive and constant movements of these parts over the 4-year observation period, it can be assumed that the rockfall activity out of the failure scar will continue to occur and may be a long term phenomenon.

Based on our measurements, the Foura da l'amd Ursina rock glaciers are slowly creeping. Interestingly, the small, tongue-like structures show a clear acceleration in comparison with the remaining rock glacier ( 1 and 3 in Fig. 10). It is conspicuous that these particular zones of acceleration mainly occur in steeper terrain. However, acceleration is not visible in all steep terrain sectors. Rather, the convex shape of the rapidly creeping structures, as well as the strong subsidence behind them implies that the rock/ice mixture accumulates above the terrain step until the frictional resistance is overcome. In a sudden acceleration the accumulated package creeps down the steep slope. This is associated with a widespread subsidence in the root zone and the process starts again. In the case of the rock glacier tongue above Val Giandains no such acceleration is visible.

Similar creep behaviour was observed on the Schwarzhorn rock glacier. Although the same dynamic pattern is visible, the creep rates as well as the terrain steps are about one magnitude higher. In the upper part of the escarpment extensive subsidence and moderate creep rates were observed. In the middle part a clear uplift combined with a strong acceleration in creep occurred. In analogy to the description of the creep dynamics at Foura da l'amd Ursina this must be a surging mass accelerating on steeper terrain. The subsidence above is induced by a dynamic extension behind the rapidly creeping package. In the lower parts of the escarpment and the neighbouring flat terrain, a compression zone with an increasingly shortening sequence of subsidence and uplift features can be seen. This finally results in a structure of furrows and ridges at the base of the escarpment (Fig. 12). The transversal ridges do not only contract in the longitudinal direction but also grow in height on their way down towards the end of the compression zone. This agrees with Kääb and Weber (2004) who postulate that transverse ridges show a pattern of continuous growth downstream under compressive flow. The observations explain the origin of the ridges as being accelerated packages of rock glacier material in steep terrain. It is likely that these packages are the initial structures that build transversal ridges under compressive pressure or in front of a resisting granular 'buttress' at the front of the rock glacier as described in Springman et al. (2012).

\section{Conclusions}

On the basis of observations using different monitoring techniques we have reached the following conclusions:

- Airborne/terrestrial laser scanning enables highly precise surface monitoring in each directional component and allows high resolution detection of creep rates.

- For the calculation of creep rates between the laser scanner DEMs, the cross correlation between two images of a high pass filtered DEM provides better a result than a cross correlation between two artificially illuminated DEMs. The high pass filter produces spatially constant contrasts in the image, even in otherwise poorly illuminated areas.

- Combining an orthophoto with an image of a comparably illuminated laser scanner DEM allows the calculation of creep rates between both datasets. The accuracy of these creep rates in moderately steep terrain is high and the signal of horizontal deformations was significant for creep rates higher than $0.5 \mathrm{~m}$ at all our sites and for creep rates higher than $25 \mathrm{~cm}$ at the Grabengufer site.

- Automatic post-processing of the obtained creep rates permits an out-filtering of single mismatches and zones of bad correlation, and indicates the accuracy obtained. 


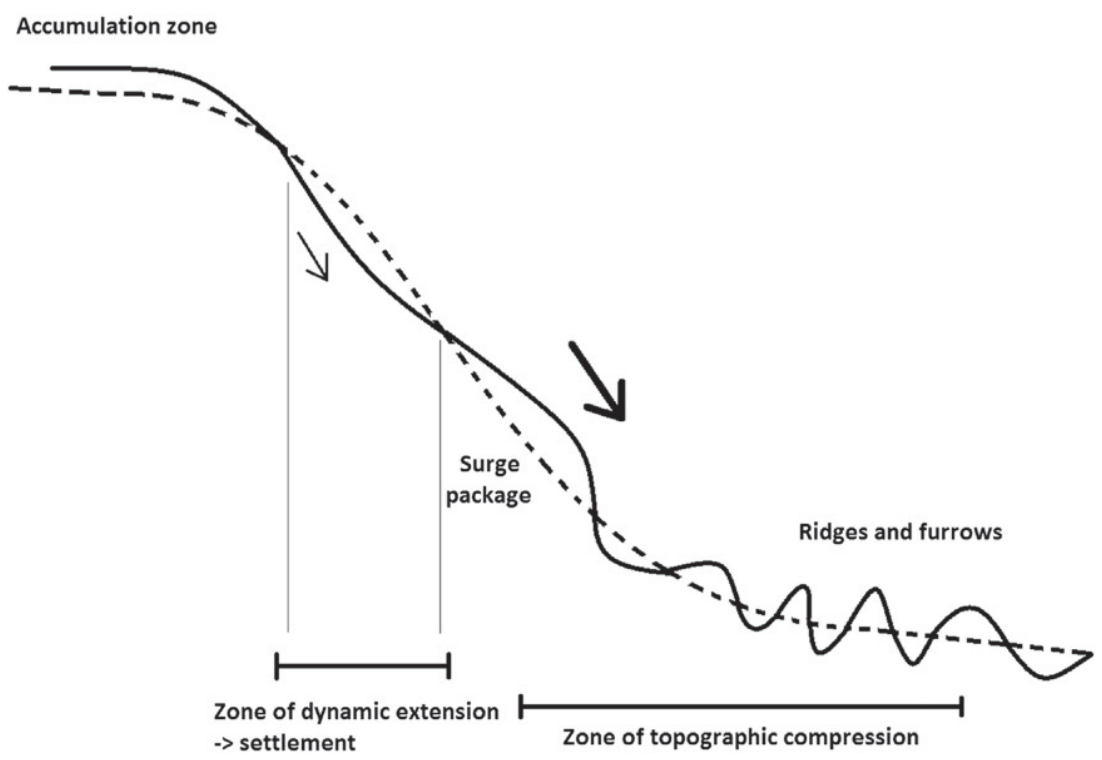

Fig. 12. Illustrative explanation for creep dynamics of rock glaciers forming transversal ridges and furrows.

- The combination of orthophotos and laser scanner data is useful to detect horizontal deformations of $25 \mathrm{~cm}$ or more. Repeated measurements are unnecessary, making this solution useful, particularly in hazardous situations.

- To define a level of significance for vertical deformations captured by multi-temporal laser scanning data, we developed a method using an extent dependent mean error. In combination with the standard deviation, this error value represents the smallest significant movement signal in a difference-raster from two DEMs, in dependence of the spatial extent of topographic changes.

- The differential creep of rock glaciers in steeper terrain is one of the major factors leading to the genesis of transversal ridges and furrows on rock glaciers.

In summary, we have proposed a practical method for the optimization of terrain monitoring in dynamic alpine permafrost terrain. Our observations of different types of rock glacier and landslide dynamics demonstrate the applicability of a combination of different remote sensing techniques and their practical use for the detailed recognition of mass movements.

\section{Acknowledgments}

The Swiss Federal Office for the Environment FOEN is thanked for providing the ADS80 images of the Grabengufer site. Geomatik AG in Zermatt carried out the surveys of the TLS control points on the site. The authors are grateful to Leo Jörger and Pauline Oberender for their valuable support in the field, and to Helibernina and Air Zermatt for their work in challenging terrain conditions. The editor and two anonymous reviewers helped to improve this paper with their constructive comments.

\section{References}

Bauer, A., Paar, G., Kaufmann, V., 2003. Terrestrial laser scanning for rock glacier monitoring. In: Phillips, M., Springman, S.M., Arenson, L.U. (Eds.), 8th International Conference on Permafrost. Swets \& Zeitlinger, Zurich, Switzerland, pp. 55-60.

Berthling, I., 2011. Beyond confusion: rock glaciers as cryo-conditioned landforms. Geomorphology 131, 98-106.

Bodin, X., Jaillet, S., Schoeneich, P., 2008. High-resolution DEM extraction from terrestrial LIDAR topometry and surface kinematics of the creeping alpine permafrost: the Laurichard Rock Glacier case study (Southern French Alps). In: Kane, D.L., Hinkel, K.M. (Eds.), 9th International Conference on Permafrost. Institute of Northern Engineering, University of Alaska Fairbanks, Fairbanks, pp. 137-142.
Bollmann, E., Klug, C., Sailer, R., Stötter, J., Abermann, J., 2012. Quantifying rock glacier creep using airborne laser scanning: a case study from Two Rock Glaciers in the Austrian Alps. In: Hinkel, K.M. (Ed.), 10th International Conference on Permafrost. The Northern Publisher, Salekhard, Russia, pp. 49-54.

Bühler, Y., Graf, C., 2012. Sediment transfer mapping in a high-alpine catchment using airborne LiDAR. In: Graf, C. (Ed.), Mattertal - ein Tal in Bewegung. Eidg. Forschungsanstalt WSL Birmensdorf, St. Niklaus, Switzerland, pp. 113-124.

Bühler, Y., Hüni, A., Christen, M., Meister, R., Kellenberger, T., 2009. Automated detection and mapping of avalanche deposits using airborne optical remote sensing data. Cold Reg. Sci. Technol. 57, 99-106.

Bühler, Y., Marty, M., Ginzler, C., 2012. High resolution DEM generation in high-alpine terrain using airborne remote sensing techniques. Trans. GIS 16, 635-647.

Delaloye, R., Strozzi, T., Lambiel, C., Perruchoud, E., Raetzo, H., 2007. Landslide-like development of rockglaciers detected with ERS-1/2 SAR interferometry. FRINGE 2007 Workshop ESA, Frascati, Italy.

Delaloye, R., Perruchoud, E., Avian, M., Kaufmann, V., Bodin, X., Hausmann, H., Ikeda, A. Kääb, A., Kellerer-Pirklbauer, A., Krainer, K., Lambiel, C., Mihajlovic, D., Staub, B. Roer, I., Thibert, E., 2008. Recent interannual variations of rock glacier creep in the European Alps. In: Kane, D.L., Hinkel, K.M. (Eds.), 9th International Conference on Permafrost Fairbanks, Alaska, pp. 343-348.

Delaloye, R., Morard, S., Abbet, D., Hilbich, C., 2010. The slump of the Grabengufer Rock Glacier (Swiss Alps). 3rd European Conference on Permafrost (EUCOP III), Svalbard, Norway.

Harris, C., Arenson, L.U., Christiansen, H.H., Etzelmüller, B., Frauenfelder, R., Gruber, S., Haeberli, W., Hauck, C., Hölzle, M., Humlum, O., Isaksen, K., Kääb, A., Kern-Lütschg, M., Lehning, M., Matsuoka, N., Murton, J.B., Nötzli, J., Phillips, M., Ross, N., Seppälä, M., Springman, S.M., Vonder Mühll, D., 2009. Permafrost and climate in Europe: monitoring and modelling thermal, geomorphological and geotechnical responses. Earth Sci. Rev. 92, 117-171.

Hobi, M., Ginzler, C., 2012. Accuracy assessment of digital surface models based on WorldView-2 and ADS80 stereo remote sensing data. Sensors 12, 6347-6368.

Kääb, A., 1999. Photogrammetry for early recognition of high mountain hazards: new techniques and applications. Phys. Chem. Earth 25, 765-770.

Kääb, A., Weber, M., 2004. Development of transverse ridges on rock glaciers: field measurements and laboratory experiments. Permafr. Periglac. Process. 15, 379-391.

Kääb, A., Kaufmann, V., Ladstädter, R., Eiken, T., 2003. Rock glacier dynamics: implications from high-resolution measurements of surface velocity fields. In: Phillips, M., Springman, S.M., Arenson, L.U. (Eds.), 8th International Conference on Permafrost A.A. Balkema Publishers, Zurich, Switzerland, pp. 501-506.

Kääb, A., Frauenfelder, R., Roer, I., 2007. On the response of rockglacier creep to surface temperature increase. Glob. Planet. Chang. 56, 172-187.

Kaufmann, V., Ladstädter, R., 2003. Quantitative analysis of rock glacier creep by means of digital photogrammetry using multi-temporal aerial photographs: two case studies in the Austrian Alps. In: Phillips, M., Springman, S.M., Arenson, L.U. (Eds.), 8th International Conference on Permafrost. A.A. Balkema Publishers, Zurich, Switzerland, pp. 525-530.

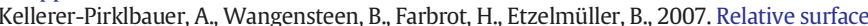
age-dating of rock glacier systems near Hólar in Hjaltadalur, Northern Iceland. J. Quat. Sci. 23, 137-151

Kenner, R., Phillips, M., Danioth, C., Denier, C., Zgraggen, A., 2011. Investigation of rock and ice loss in a recently deglaciated mountain rock wall using terrestrial laser scanning: Gemsstock, Swiss Alps. Cold Reg. Sci. Technol. 67, 157-164.

Lambiel, C., Delaloye, R., 2004. Contribution of real-time kinematic GPS in the study of creeping mountain permafrost: examples from the Western Swiss Alps. Permafr. Periglac. Process. 15, 229-241. 
Lugon, R., Stoffel, M., 2010. Rock-glacier dynamics and magnitude-frequency relations of debris flows in a high-elevation watershed: Ritigraben, Swiss Alps. Glob. Planet. Chang. 73, 202-210.

Roer, I., Haeberli, W., Avian, M., Kaufmann, V., Delaloye, R., Lambiel, C., Kääb, A., 2008. Observations and considerations on destabilizing active rock glaciers in the European Alps. In: Kane, D.L., Hinkel, K.M. (Eds.), 9th International Conference on Permafrost. Institute of Northern Engineering, University of Alaska Fairbanks, Fairbanks, pp. 1505-1510.

Roesgen, T., Totaro, R., 1995. Two-dimensional on-line particle imaging velocimetry. Exp. Fluids 19, 188-193.
Schwalbe, E., Maas, H.-G., Dietrich, R., Ewert, H., 2008. Glacier velocity determination from multi temporal terrestrial long range laser scanner point clouds. 21st ISPRS Congress, Peking. 457-462.

Skaloud, J., Vallet, J., Keller, K., Vessyere, G., Kölbl, O., 2005. ION GNSS 2005 Congress, Long Beach, California. ION GNSS 2005 Congress, Long Beach, California.

Springman, S.M., Arenson, L.U., Yamamoto, Y., Maurer, H., Kos, A., Buchli, T. Derungs, G., 2012. Multidisciplinary investigations on three rock glaciers in the swiss alps: legacies and future perspectives. Geogr. Ann. Ser. A Phys. Geogr. 94, 215-243. 